\author{
術前診断しえた閉鎖孔へルニアの 1 例 \\ 済生会奈良病院外科 \\ 山下潤仲川恵三島田健太郎 \\ 奈良県立医科大学第 1 外科 \\ 中 野 博 重
}

Computed Tomography (以下 CT), 注腸造影，イレウス管造影にて術前診断しえた 閉銷孔へルニアの 1 例を経験したので報告する. 症例は89歳，女性でイレウス症状と Howship Romberg 徵候を認めた. 注腸造影およびイレウス管造影にて閉銷孔へルニア を疑い，CTにて確定診断を得ることができた。待期的に開腹術を施行したところ，小腸 には循環障害を認めず，腸管切除することなく閉銷孔を閉じ手術を終了した，術後は特 に合併症なく経過し軽快退院した。

本症に特徵的な CT 像としては, 恥骨筋後方に認められる water density mass, 外閉 鎖筋構造の乱れなどがあげられる。原因不明のイレウス患者に対して本症を疑った場合， CT は非侵謷的かつ簡便であり，確定猃断が可能なことから早期に行うべき検查法であ ると考える。

索引用語：閉鎖孔へルニア,イレウス管造影, CT

はじめに

閉鎖孔へルニアは比較的稀な疾患であり，本邦では 300例余の報告があるにすぎない.本疾患の術前診断率 は低く, 嵌頓し原因不明のイレウスとして, 開腹時に 診断されることが多い。診断の遅れからくる嵌頓時間 は長く, 手術死亡率も比較的高いのが現状であり, 早 期診断, 早期治療が必要である.今回われわれは, CT, 注腸造影，およびイレウス管よりの選択的小腸造影に て術前診断しえた閉鎖孔へルニアの1例を経験したの で若干の文献的考察を加えて報告する.

$$
\text { 症例 }
$$

患者：89歳，女性.

主訴：嘔吐, 腹痛.

家族歴：特記すへきことなし。

既往歴：特記すべきことなし。

現病歴：1990年 9 月18日, 嘔気, 哣吐出現するも放 置していた。 9 月25日, 右下腹部痛および腹満感出現 し，再び嘔吐を認めたため，9月26日，近医を受診. 腹部単純写真にてイレウスを疑われ，ガストログラ フィンを用いて小腸造影を施行するも閉塞部位は同定
てきず，同日，精查目的に当院紹介入院となった。

入院時現症：身長 $145 \mathrm{~cm}$ ，体重 $35 \mathrm{~kg}$. 結膜に筫血， 黄㾝認めず。胸部は打聴診上異常なし. 腹部は下腹部 中心に埱満し，圧痛を記めるが，筋性防御はない，腹 部および大服部に腫瘤を触知しない. 軽度腹水の貯留 を認める. 右腰部から右大酿部に疼痛あり。

入院時検查成績：軽度實血を認める以外特に異常は ない.

腹部単純 $\mathrm{X}$ 線写真 : 近医受診時の仰臥位での腹部 単純 X 線写真では, 拡張した小腸（特に回腸）のガス 像を認めた。大腸ガスはほとんど認められず，下部小 腸での閉塞が考えられた（図 1).

閉塞部位同定のため入院後ただちに注腸造影検查を 施行した.

注腸造影：右閉鎖孔付近の小腸に急峻な先細り状の 完全閉塞を認めた。大腸には狭窄性病変は認められな かった (図2).

また，X線透視下でイレウス管を経鼻的に挿入し た。これにより腸管は良好に滅圧され，腹痛などのイ レウス症状は軽隇した、イレウス管の先進が停止した 時点て，イレウス管よりの造影を施行した.

イレウス管造影：ガストログラフィンを用いて選択 


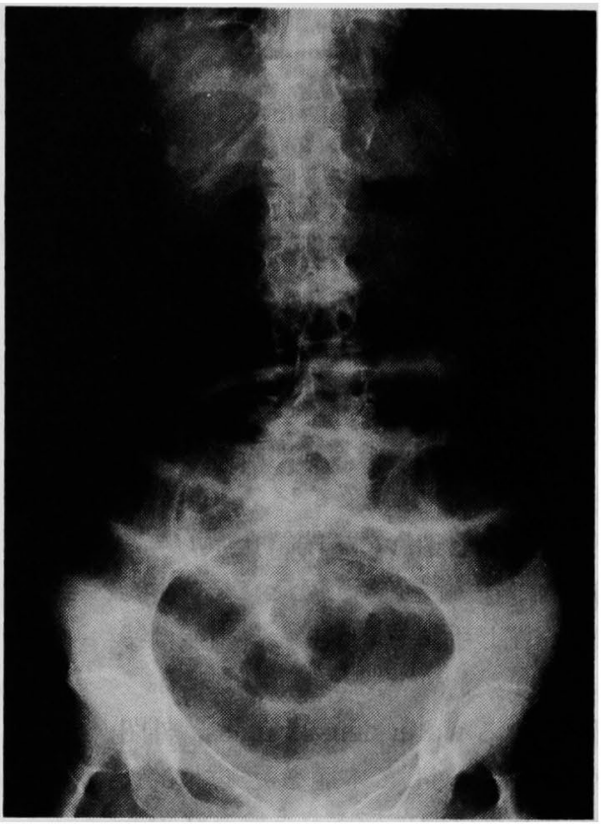

図 1 腹部単純 X 線写真：拡張した小腸 (特に回腸) のガス像を認めた。

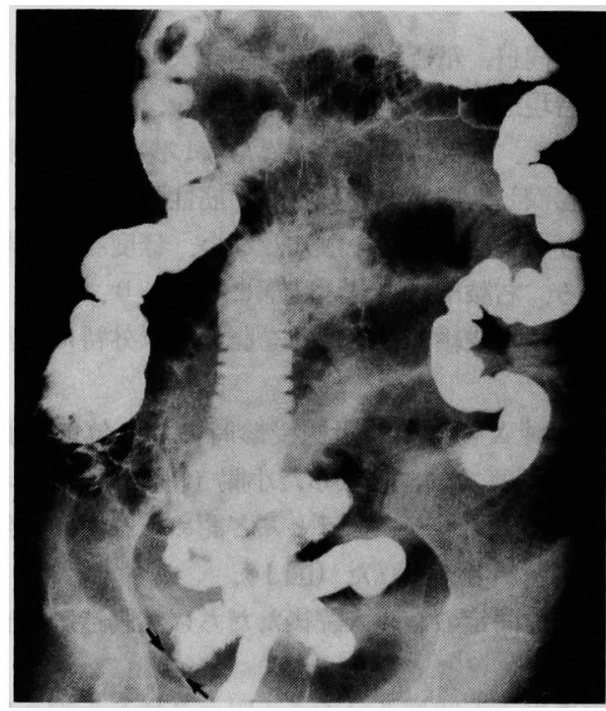

図2 注腸造影：右開鎖孔付近の小腸に先細り状の完 全閉塞を認めた（矢印).

的小腸造影を行った，造影剂は右閉鎖孔付近て球形の 閉塞像を示した後, 進行はなく, 体位変換によっても この部の移動は見られなかった（図３）。

以上の造影所見より右閉銷孔へルニアを疑い，骨盤 部 CT 検查を施行した。

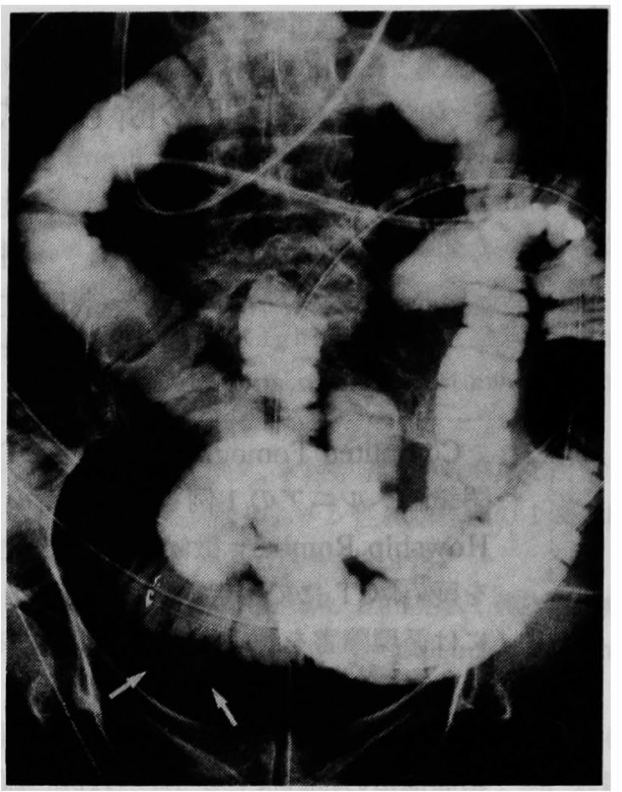

図 3 イレウス管造影：造影用は右閉鎖孔付近の小腸 で球形の閉塞像を示した（矢印）。
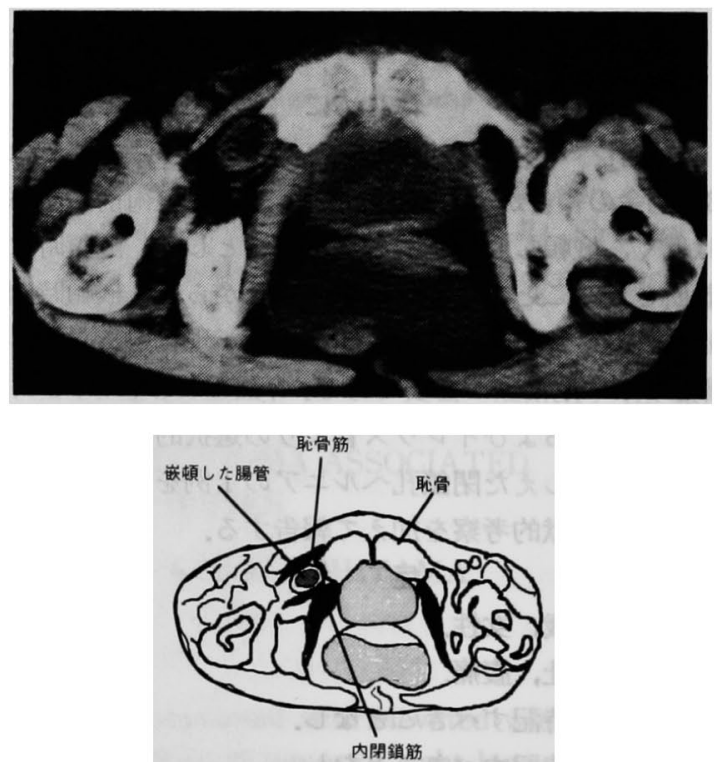

図 4 骨盤部 CT 像: 右恥骨筋と右内閉鎖筋の間に water density の類円形尰留を認めた。

CT 検査：恥骨結合レベルにて右恥骨筋と右内閉鎖 筋の間に, 外側が高濃度で内側が低濃度の類円形腫痹 を認めた. 内部は water densityであり嵌頓した腸管 と考えられた（図4). 


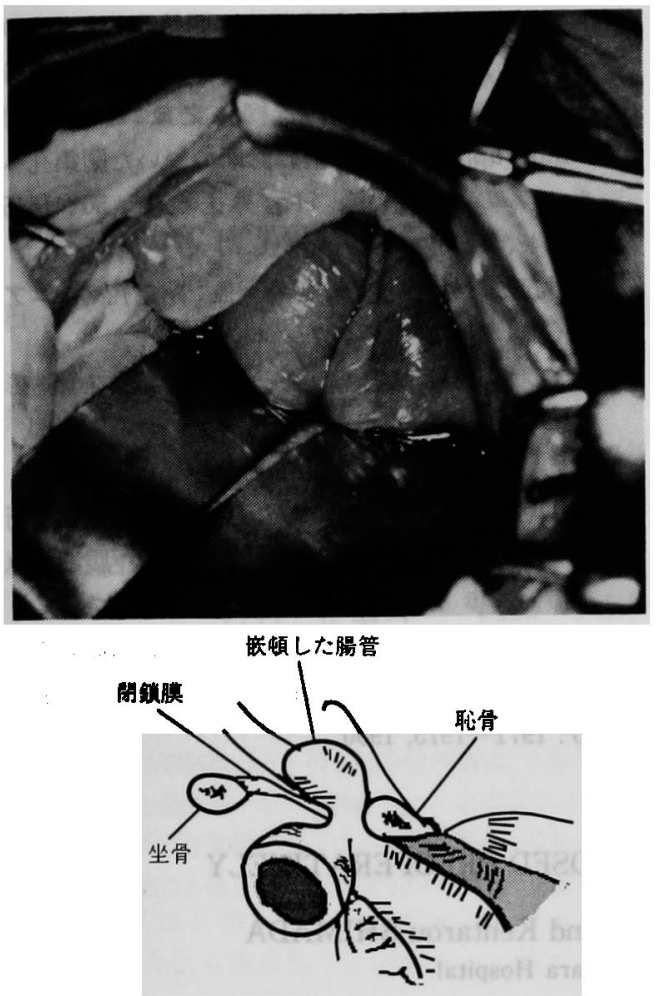

図 5 手術所見：右閉鎖孔に回腸が Richter 型に嵌入 していた。循罢障害は認めなかった。

以上より右閉鎖孔へルニア嵌頓によるイレウスと診 断し, 手術を施行した。

手術所見：全身麻酔下に下腹部正中切開にて開腹し た．槳葆性の腹水を少量認めたが，小腸はイレウス管 によって良く減圧され，著明な拡張はなかった．回腸 末端より約 $1 \mathrm{~m}$ 口側で，小腸壁の一部が右閉鎖孔に嵌 入した，いわゆる Richter 型のヘルニアを認めた（図 5).へルニア門を鋭的および鈍的に拡大し，腸管を愛 護的に注意深く率引することにより整復した，嵌頓部 腸管には循環障害は見られなかった，次にヘルニア を反転して引き出し，ヘルニア門のレベルで切除した 後、テキッン糸を用いて連続縫合にて閉鎖した。

術後経過：術後経過は良好で, 術後23日目に軽块退 院した。

\section{考 察}

閉鎖孔は坐骨と恥骨によって囲まれた大きな骨空隙 で，内外閉錤筋と閉鎖膜によって閉ざされている，孔 の前上方に閉鎤動静脈，神経が通る閉鎖管が存在しこ の部は抵抗が薄弱なためへルニアの発生部位となる。 本症は比較的稀な疾患で本邦で300例余の報告が
あるにすぎない゙．臨床的には高龄でやせた多産の女 性に多いとされている(12). ヘルニア内容は小腸が多 く,ヘルニア門が小さいために腸壁ヘルニア (Richter' s hernia）が多いことも特徵である ${ }^{2}$. 理学的所見の代 表としてはイレウス症状と Howship-Romberg sign (以下 HRS)があげられる. HRS は閉鎖神経のへルニ ア内容による圧迫症状で，大駺内側から滕にかけて生 じる知覚異常や疼痛である。しかし，本徵候は retrospectiveにみて診断されることがほとんどで)，われ われの症例に扔いても術前にHRSに気付くことがて きなかった。

本症の診断根拠は, HRS が最多で, 次いで小腸造影, 腹部単純 X 線写真の順と言われているが31, 近年, 画像 的に確診しえた症例も報告されているい) 文．われわれ はイレウス管造影および注腸造影にて本症を疑い,CT にて本症と診断しうる特徵的所見を得ることができ た. CT 像の特徵としては，恥骨筋後方に認められる water density mass (air fluid level を形成すること もある）もしくは腸管ループ，内外閉鎖筋構造の乱れ (左右対称性の消失)，閉鎖孔近傍腸管の㹡張などがあ げられる4) ． 原因不明のイレウス患者のCT 検査で は，本疾患の可能性も考元骨盤腔内だけでなく骨盤外 の所見も見逃さないようにする必要があると思われ る.

イレウス管造影所見の特徵としては, 閉鎖孔付近で の造影剤の先細り像と中断, 口側腸管の㹡張像および 悪性疾患を思わせる不整レリーフ像がみられないこと などがあげられるが8199，われわれの症例では球形の中 断像を呈した. また，閉塞のために腸管の浮腫が生じ, Richter 型ヘルニアにもかかわらず完全閉塞像を示し たものと考えられた、イレウス管造影は，イレウス管 の閉塞部位への到達までに時間を要するのが難点であ るが，診断と減圧の両者に利用でき，待機手術が可能 な症例では有利であると思われる，早期診断という意 味では注腸造影のほうが有利とする報告もあるが(0), 閉塞部位が回腸末端部より比較的遠位にある場合には 十分に閉塞部を描出できないこともある。いずれにし ても両造影検査とも高齢患者にとってはかなりの負担 であり，また確実性，特異性に欠けるきらいがあるよ うに思われる。その点 CT は非侵襲的検查法であり， 確定診断が可能なことから第一選択の検査法としてよ いと思われる。

おわりに

CTにより確実な術前診断を得た閉鎖孔ヘルニアの 
1 例について述へた。. 本症診断の第一歩は HRS の認 識にあるとされてきたが, 本症を常に念頭に置き，各 種画像診断を積極的に利用する姿勢があれば，本症の 診断は容易であると思われる。

\section{文献}

1) 船戸崇史, 市橋正喜, 乾 博史他：非観血的整復術 後に手術を行った閉銷孔へルニアの1例。日消外 会誌 $23: 810-814,1988$

2）宮田潤一, 米山桂八, 固武健二郎他：異時性に両側 発生した閉銷孔へルニアの 1 例および本邦報告例 の統計的検討. 臨外 39:1641-1644, 1984

3）森村尚登, 西山 潔, 渡会伸治他：手術前に診断て きた閉銷孔ヘルニアの1例ならびに本邦報告246 例の文献的考察. 日臨外医会誌 $49: 132-138$, 1988

4) Cubillo E: Obturator hernia diagnosed by computed tomography. AJR 140 : 735-736, 1983
5）岩尾畫夫, 寒竹泰弘, 福永昌幸：閉鎖孔へルニアの CT 診断.腹部救急診療の進歩 $9: 861-864,1989$

6）近森文夫，岡村隆夫，青柳㫃之他：Computed tomographyにより術前に診断のついた閉銷孔へ ルニアの 1 治験例。日臨外医会誌 $50: 1645$ $-1648,1989$

7）白井茂夫, 水流浩志, 安田幸彦他：閉鎖孔へルニア のCT. 臨放線 35:427-430, 1990

8）円谷 博, 小坂博美, 斉藤正光他：イレウス管造影 により術前診断を得た開鎖孔ヘルニアの 1 症例。 消外 6: 499-501, 1983

9）川口昭男, 渡部誠一郎, 白石円樹他：小腸造影で術 前診断した閉鎖孔へルニアの 2 治験例. 腹部救急 診療の進歩 $9: 351-354,1989$

10）山本 均, 伊藤真悟, 内田 海他：腸造影および CTが有用であった閉銷孔へルニアの 1 例. 消外 13: 1971-1975, 1990

\title{
A CASE OF OBTURATOR HERNIA DIAGNOSED PREOPERATIVELY
}

\author{
Jun YAMASHITA, Keizou NAKAGAWA and Kentarou SHIMADA \\ Department of Surgery, Saiseikai Nara Hospital
}

Hiroshige NAKANO

First Department of Surgery, Nara Medical University

This paper presents a case of obturator hernia preoperatively diagnosed by computed tomography, retrograde intestinography and gastrografin study with an ileus tube.

A 89-year-old woman was admitted to the hospital because of the symptoms of ileus and Howship Romberg sign. Retrograde intestinography and gastrografin study with an ileus tube indicated a possibility of obturator hernia. Definite diagnosis, however, was made by computed tomography. Elected operation was performed, and no circulatory disturbance in the small intestine was disclosed. The operation was ended by closure of the right obturator foramen, without enterectomy. The patient had an uneventful postoperative course to be discharged in due time.

The key findings of computed tomography characteristic of the disease include a water density mass located in the posterior to the pectineus muscle and deformed muscular bands of external obturator muscle.

When a patient with ileus of unknown origin is suspected to have this disease, computed tomography, which can offer the definite diagnosis safely and easily, should be carried out in an early stage. 